\title{
Penentuan Kadar Lemak Secara Non-Destruktif Pada Bubuk Biji Kakao (Berbasis Nirs-Partial Least Square) Dengan Menerapkan Metode Mean Normalization Dan De- Trending \\ Non-Destructive Determination of Cocoa Bean Fat Content by NIRS (Comparissions Between Mean Normalization and De-Trending)
}

\author{
Muaida Alfia*, Zulfahrizal, Agus Arip Munawar \\ Program Studi Teknik Pertanian, Fakultas Pertanian, Universitas Syiah Kuala
}

\begin{abstract}
Abstrak. Saat ini untuk menentukan kadar lemak pada biji kakao dilakukan dengan mengekstrak biji kakao menggunakan pelarut tertentu yang memakan waktu cukup lama, sehingga metode penentuan mutu secara cepat dan tepat diperlukan untuk menghasilkan komoditas kakao standar mutu tinggi yang dapat diwujudkan dengan metode near infrared reflectance spectroscopy (NIRS). Tujuan yang ingin dicapai dari penelitian ini membandingkan data spektrum antar pretreatment mean normalization (MN) dan de-trending dan (DT) dalam mengkoreksi spektrum NIRS yang dihasilkan serta mengembangkan metode non-destruktif NIRS dalam menduga kandungan lemak pada bubuk biji kakao. Penelitian ini dilakukan di Laboratorium Instrumentasi dan Energi Program Studi Teknik Pertanian pada bulan Maret sampai Mei 2016. Hasil penelitian yang diperoleh bahwa metode NIRS menggunakan preatreatment de-trending dan mean normalization pada panjang gelombang 2300-2400 nm merupakan panjang gelombang yang paling relevan untuk menduga kadar lemak pada bubuk biji kakao. Pendugaan PLS yang didukung pretreatment telah menghasilkan pendugaan yang tergolong good model performance. Pada pendugaan kadar lemak PLS yang sangat baik dalam meningkatkan kinerja PLS pada cross validation adalah de-trending.
\end{abstract}

Kata kunci : Biji Kakao, NIRS, Kadar Lemak, Metode Non-Destruktif.

Abstract. Determining fat content in cocoa beans is generally performed by extracting cocoa beans using certain solvent extraction which takes a long time. Determining quality method quickly and exactly required to produce the commodity of high quality standard cocoa that is realized by of near infrared reflectance spectroscopy (NIRS) method. The aim of this research is to compare the spectral data pretreatment mean normalization (MN) and de-trending and (DT) in correcting the NIRS spectrum which is namely and to develop of non-destructive NIRS method in predicting the fat content in cocoa powder. This research was conducted in Instrumentation Laboratory and Energy of Agriculture department from March to May 2016. the results of the research obtained that the NIRS method used de-trending and mean normalization spectra correction methods at a wave-length range of 2300-2400 $\mathrm{nm}$, found to be the most relevant to estimate the fat content in cocoa powder. The estimation of PLS been produced a of good model performance.

Keywords: Cocoa beans, NIRS, Fat Content, Non-Destructive Methods.

\section{PENDAHULUAN}

Indonesia merupakan salah satu negara pembudidaya tanaman kakao yang luas di dunia. Indonesia berdasarkan data ICCO (International Cocoa Organization) merupakan produsen biji kakao nomor tiga dunia setelah Pantai Gading dan Ghana. Tahun 2014 produksi biji kakao Pantai Gading diperkirakan sebesar 1.746.000 ton, Ghana 897.000 ton dan Indonesia sebesar 375.000 ton (ICCO, 2015). Aceh sendiri pada tahun 2013 menyumbang sebesar 34.795 ton. Namun kenyataannya industri pengolahan kakao dan industri cokelat justru berada di negara-negara Eropa (Belgia, Inggris, dan Swiss), Amerika Serikat, serta Singapura dan Malaysia sehingga nilai tambah tidak dinikmati Indonesia sebagai penghasil biji kakao (BPS, 2013). 
Saat ini produksi dan produktivitas kakao di Indonesia mengalami penurunan. Selain tingkat produktivitas yang kecil dibandingkan dengan klon atau tanaman yang ada, aspek mutu juga mengalami masalah. Rendahnya mutu dan daya saing produk dipengaruhi oleh banyak faktor dan salah satunya adalah aspek pasca panen yang belum dilakukan dengan baik. Lemak merupakan komponen termahal dari biji kakao sehingga nilai ini dipakai oleh konsumen sebagai salah satu tolak ukur penentuan harga. Kisaran kadar lemak biji kakao Indonesia adalah antara 49\% - 52\% (Mulato et al. 2010). Menurut panduan yang dikeluarkan Badan Standarisasi Nasional (2008), untuk menentukan kadar lemak dilakukan dengan mengekstrak biji kakao menggunakan pelarut tertentu yang memakan waktu cukup lama.

Metode penentuan mutu secara cepat dan tepat diperlukan untuk menghasilkan komoditas kakao standar mutu tinggi yang disyaratkan negara konsumen. SNI menetapkan standar mutu biji kakao dilihat secara fisik seperti kadar air, kontaminasi terhadap serangga, benda asing dan berbagai aroma yang dapat merusak aroma khas kakao (BSN, 2008). Secara khusus Mulato et al (2009) mengatakan bahwa mutu kakao ditentukan oleh rendemen lemak, aroma dan citarasa, karena komponen-komponen inilah yang biasanya menentukan sensasi dalam menikmati coklat.

Near Infrared Reflectance Spectroscopy (NIRS) merupakan salah satu metode pengukuran non-destruktif yang banyak digunakan dan dikembangkan. Teknologi NIRS dapat menganalisa dengan cepat, tidak menimbulkan polusi, penggunaan preparat contoh yang sederhana, dan tidak merusak sampel. Cen dan He (2007) menyatakan melalui pengembangan ilmu komputer dan kemometrika, kemampuan aplikasi teknik NIRS menjadi lebih popular dan menarik banyak perhatian para peneliti dalam bidang pangan. Komponen dengan presentase konsentrasi $0.1 \%$ dapat dideteksi dan dievaluasi menggunakan NIRS. Sudah seharusnya dikembangkan metode untuk pengukuran mutu kakao yang memenuhi syarat cepat dan akurat.

\section{METODE PENELITIAN}

Penelitian telah dilaksanakan di Laboratorium Instrumentasi, dan Energi, Program Studi Teknik Pertanian, Fakultas Petanian, Universitas Syiah Kuala, Banda Aceh.

\section{Alat dan Bahan}

Alat yang digunakan pada penelitian ini adalah FT-IR IPTEK T-1516, perlengkapan uji kadar lemak, perlengkapan pembubukan biji kakao dan unscrambler software ${ }^{\circledR} X$ version 10.1 .

Bahan yang digunakan pada penelitian ini adalah biji kakao yang didapat dari Jember berupa yang non fermentasi dan difermentasi.

\section{Pesiapan Bubuk Biji Kakao}

Penelitian ini menggunakan buah kakao varietas lindak yang didapat dari Jember berupa yang non fermentasi dan difermentasi. Kemudian kakao tersebut disimpan selama 3 hari di ruangan dengan suhu $25^{\circ} \mathrm{C}$ yang bertujuan untuk menstabilkan suhu pada biji kakao. Selanjutnya dilakukan penghancuran pada biji kakao dengan menggunakan alat penghancur (blender) dan dihasilkan bubuk kasar. Selanjutnya diayak dengan ayakan berukuran 24 mesh untuk mendapatkan bubuk kakao yang halus dengan ukuran yang seragam. Jumlah sampel sebanyak 30 sampel yang terdiri dari 15 sampel yang non fermentasi dan 15 sampel yang difermentasi. 


\section{Pengambilan Spektrum Bubuk Biji Kakao}

Selanjutnya dilakukan kalibrasi background/reference pada alat FT-IR IPTEK T-1516 tiap jam. Proses bekerjanya alat menggunakan integrating sphere. Digunakan software termo integration $^{\circledR}$ untuk pengendalian kerja alat untuk pembuatan workflow dan menjalankan workflow, untuk running alat dilakukan oleh termo operation ${ }^{\circledR}$. Selang gelombang yang dipilih adalah antara 1000-2500 $\mathrm{nm}$ dengan interval $0.4 \mathrm{~nm}$. Workflow dibuat untuk mengatur alat agar bekerja untuk mengakuisisi spectrum absorban, memindai sampel sebanyak 64 kali perproses lalu dirata-ratakan hasilnya, kemudian disimpan hasil pemindaian dalam 3 bentuk file yakni *.SPA. *.JDX dan *.CSV. Akuisisi spektrum bubuk biji kakao dengan pengambilan spektrumnya yaitu memasukkan bubuk biji kakao ke dalam petridish (diameter $3 \mathrm{~cm}$, tebal 1,9 $\mathrm{cm}$ ) yang tersedia lalu diatur berputar 360 derajat selama proses pemindaian sampel. Data absorban diperoleh dengan cara menstransformasikan nilai reflektan/pantulan kedalam bentuk $\log (1 / \mathrm{R})$. Pengolah data spektrum menggunakan unscrambler software ${ }^{\circledR} X$ version 10.1 . Pretreatment yang digunakan adalah de-trending (DT) dan mean normalization (MN).

\section{Kadar Lemak}

Pengukuran kadar lemak menggunakan Metode Soxhlet (Zulfahrizal, 2014) Prosedur pengukuran dimulai dengan mengeringkan labu takar bersama beberapa batu api selama 1 jam pada suhu $105^{\circ} \mathrm{C}$. Lalu didinginkan dalam exicator. Kemudian ditimbang, hasilnya dicatat sebagai nilai L. Sampel sebanyak 10 gram dimasukkan dalam extration thimble kemudian ditutup dengan kapas dan extration thimble ditempatkan dalam perangkat soxhlet. Selanjutnya menambahkan 100-150 ml n-hexana kedalam labu takar. Maka proses ekstraksi dapat dimulai. Ekstraksi dilakukan selama 6 jam pada suhu $95^{\circ} \mathrm{C}$ sampai $n$-hexana bersih. Selanjutnya $n$ hexana diuapkan dengan rotary evaporator sampai yang tertinggi adalah cairan lemak. Lalu labu takar yang mengandung lemak dikeringkan dalam oven pada suhu $105^{\circ} \mathrm{C}$ selama 30 menit. Terakhir, labu takar didinginkan di dalam exicator. Setelah dingin, labu takar ditimbang kembali dan dicatat sebagai LA. Perhitungan jumlah kadar lemak (KL) mengikuti persamaan :

$$
\mathrm{KL}(\%)=\frac{(L A-L) \times 10.00}{10 \times \text { material kering }(\%)}
$$

Dimana : $\mathrm{L}=$ Berat awal labu takar $(\mathrm{gr})$

LA = Berat akhir labu takar (gr)

\section{Pengembangan Model Kalibrasi Kadar Lemak dalam Bubuk Biji Kakao}

Keseluruhan data dipakai sebagai dataset kalibrasi yang digunakan untuk membangun model prediksi kadar lemak. Kemudian dilakukan validasi silang ( $K$-fold cross validation) dengan jumlah segment (fold) adalah 10. Model prediksi dibangun dengan menggunakan metode Partial Least Squares (PLS) yang dibandigkan dengan hasil uji laboratorium.

Evaluasi keakuratan dan kehandalan model dievaluasi dengan melihat parameter statistik yang meliputi: koefisien kolerasi (r), koefesien determinasi $\left(\mathrm{R}^{2}\right)$, residual predictive deviation (RPD) index, root mean square error cross validation (RMSECV), root mean square error calibration (RMSEC), latent variable (LV), dan dRMSE . Model persamaan kalibrasi data serapan dibandingkan dengan data aktual dan dilihat nilai r, RMSEC, RMSECV, RPD, dan LV. Model yang bagus memiliki nilai $r$ dan $\mathrm{R}^{2}$ yang tinggi, RMSEC yang rendah, RPD > 
1.5 jumlah latent variable $<9$; RMSEC, RPD, dan dRMSE dicari dengan persamaan (Florez, 2009 ; Jha, 2006 ; Nicolai, 2007 ; Zulfahrizal, 2015 ${ }^{\text {b }}$ :

$$
\begin{gathered}
\mathrm{dRMSE}=|R M S E C V-R M S E C| \\
R M S E C, R M S E C V=\sqrt{\frac{1}{n} \sum_{i=1}^{n}\left(\hat{y}_{i}-y_{i}\right)} \\
R P D=\frac{S D}{R M S E C V}
\end{gathered}
$$

Dimana : $\hat{y}_{\mathrm{I}}=$ parameter nilai dari dugaan awal model sampel ke-i.

$\mathrm{y}_{\mathrm{i}}=$ parameter nilai hasil pengukuran laboratorium untuk sampel ke-i

$\mathrm{n}=$ jumlah sampel dalam kalibrasi atau validasi.

$\mathrm{SD}=$ standar deviasi untuk data aktual.

\section{HASIL DAN PEMBAHASAN \\ Spektrum NIRS}

Pengukuran spektra yang digunakan pada rentang panjang gelombang 1000-2500 nm dengan interval $0.4 \mathrm{~mm}$ sebanyak 30 sampel. Selang panjang gelombang dibawah $1000 \mathrm{~nm}$ sengaja dipotong karena cenderung tidak memberikan informasi yang dibutuhkan. Pada panjang gelombang 1000-2500 nm memperlihatkan spektrum dengan beberapa puncak-puncak yang terbentuk. Puncak spektrum NIR ini dipengaruhi oleh komponen kimia di dalam bahan dan karakter fisik bahan. Masing-masing puncak dapat diinterpretasikan memiliki kandungan kimia yang berbeda. Spektrum bubuk biji kakao yang didapat dari pengukuran spektra dengan alat NIRS dapat dilihat berdasarkan Gambar 1 pada a. Raw Spektrum.

Selanjutnya terlihat jelas pada b. Mean Normalization (Gambar 1.) perbedaan antara adanya pretreatment dan non pretreatment. Hal ini dapat dilihat dari variasi yang muncul antar spektrum. Pemakaian pretreatment mean normalization dilakukan untuk menghilangkan pengaruh perbedaan ukuran partikel sampel uji dan memperbesar rentang nilai reflektan serta akan memperlebar nilai spektra serta memproposionalkan nilai spektra dari dua nilai spektra dengan kandungan yang sama. Sehingga spektrum yang didapat menjadi lebih berhimpit (sama) untuk bahan dengan kandungan kimia yang sama.

Berikutnya pada c. De-Trending (Gambar 1.) digunakan untuk menghapus trend nonlinear dalam data. Pemberian pretreatment bertujuan untuk mengurangi pengaruh interferensi gelombang noise yang menyebabkan kumpulan spektrum bubuk biji kakao lebih halus dan lebih rapat.
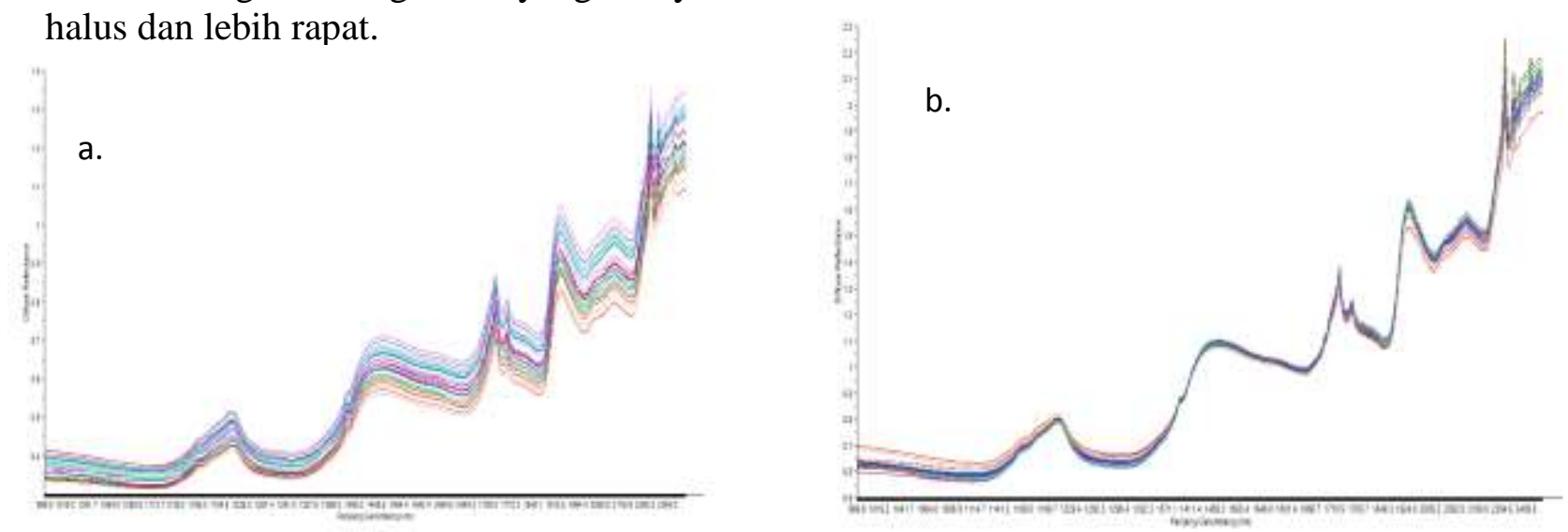


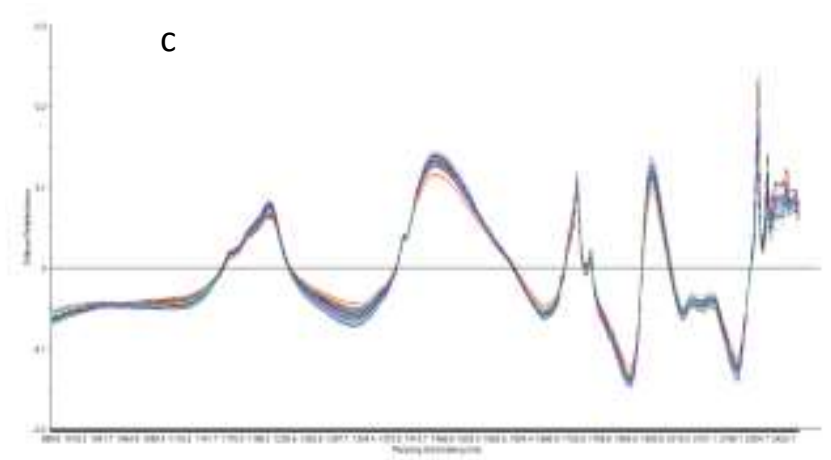

Gambar 1. Spektrum NIRS pada Bubuk Biji Kakao a. Raw Spektrum b. Mean Normalization c. De-Trending

\section{Loading Plot Spektrum}

Berdasarkan Gambar 2. salah satu sampel bubuk biji kakao diambil spektrumnya untuk mempermudah dalam interpretasi spektrum. Letak kandungan kadar lemak bubuk biji kakao berada pada panjang gelombang 1200-1220 nm, 1700-1740 nm, dan 2300-2400 nm. Rentang panjang gelombang ini mirip seperti yang didapat pada penelitian Zulfahrizal (2014) untuk biji kakao utuh, letak kandungan kadar lemak berada pada panjang gelombang 1160-1220 nm, 1650-1760 nm, 2300-2400 nm. Namun pada penelitian ini puncak yang menandakan keberadaan kadar lemak tampak lebih jelas, hal ini terjadi karena pengurangan kadar air pada saat pembubukan. Ternyata dapat disimpulkan bahwa kandungan kadar lemak pada biji kakao maupun bubuk biji kakao mempunyai tipikal spektrum yang sama.

Berdasarkan Gambar2. pada a. Mean Normalization dimana panjang gelombang yang menghasilkan getaran ikatan $\mathrm{CH}$, dan $\mathrm{CH}_{n}$ adalah 1680 - 1760, dan $2300-2400$. Panjang gelombang 2300-2400 $\mathrm{nm}$ merupakan panjang gelombang yang relevan yang ditandai dengan terjadinya stretching sehingga dapat disimpulkan bahwa pada panjang gelombang tersebut yang mencirikan secara khas kandungan kadar lemak pada bubuk biji kakao.

Selanjutnya pada b. De-Trending (Gambar 2). menunjukkan loading plot de-trending terlihat puncak-puncak yang menandakan kandungan kimia kadar lemak dari bubuk biji kakao. Getaran yang terjadi pada panjang gelombang 1100-1150 nm, 1200-1300 nm, 1650-1760 nm, dan 2300-2400 nm menunjukkan adanya ikatan C-H (penanda keberadaan kadar lemak). Sama halnya dengan pretreatment mean normalization pada panjang gelombang 2300-2400 nm merupakan panjang gelombang yang relevan yang ditandai dengan terjadinya stretching sehingga dapat disimpulkan bahwa pada panjang gelombang tersebut yang mencirikan secara khas kandungan kadar lemak pada bubuk biji kakao.

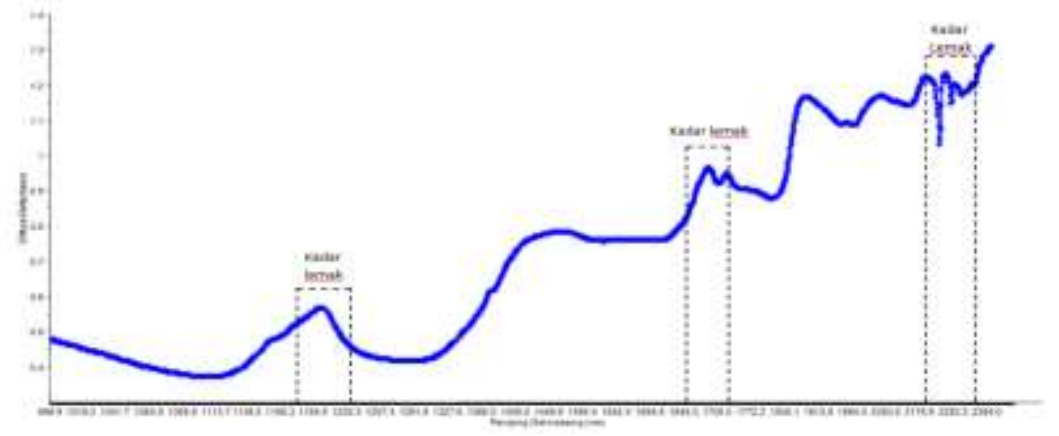



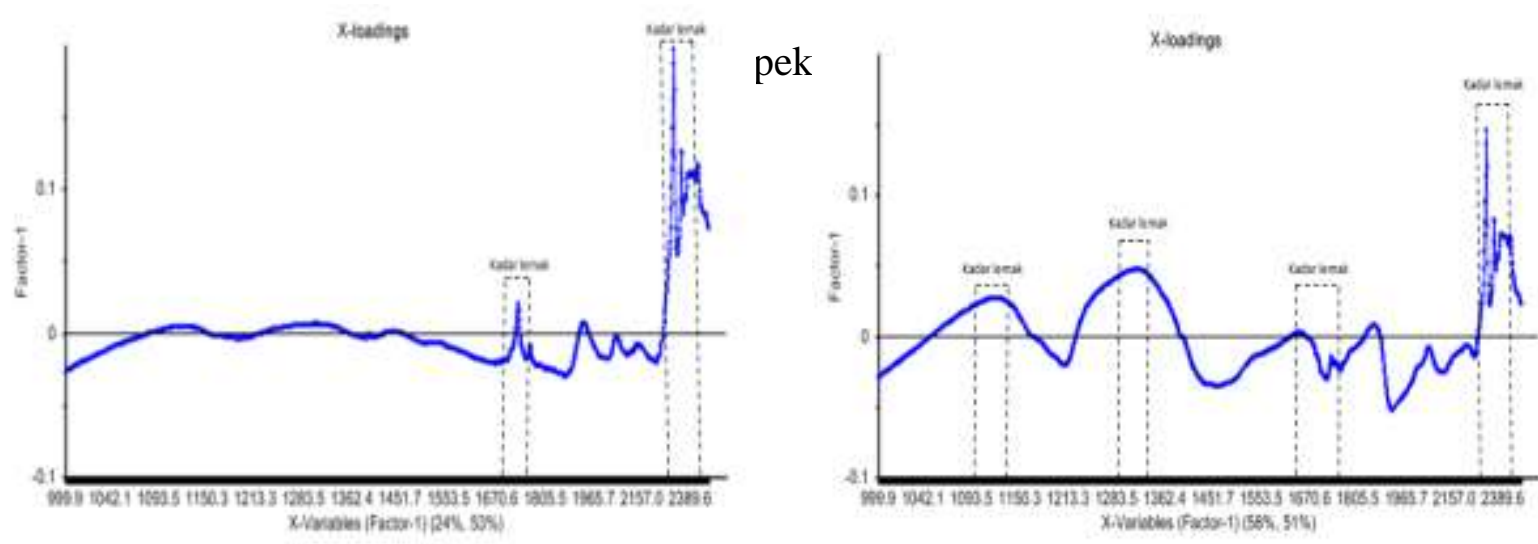

Gambar 2. Loading Plot untuk Pretreatment a. Mean Normalization b. De-Trending

\section{Kalibrasi dan Validasi Silang (Cross Validation)}

\section{Kalibrasi}

Biji kakao yang digunakan pada penelitian ini memiliki selang kadar lemak antara $37,8 \%-45,7 \%$. Tujuan dari kalibrasi adalah untuk membangun model persamaan matematik yang dapat digunakan untuk memprediksi kandungan kimia bahan tanpa harus melakukan pengukuran langsung yang merusak bahan.

Hasil pendugaan kalibrasi non pretreatment menghasilkan nilai koefisien korelasi (r) yang cukup tinggi yaitu 0,93. Menurut William dan Norris (1990) nilai r di atas 0,90 sudah baik. Koefisien determinasi $\left(\mathrm{R}^{2}\right)$ yang baik yaitu 0,87 . Menurut Karoui et al. (2005) nilai $\mathrm{R}^{2}$ antara 0,82-0.90 menyatakan dugaan baik. Sementara nilai error (RMSEC) yang cukup kecil yaitu 0,79. Menurut William dan Norris (1990) nilai error lebih kecil dari standar deviasi data aktual sudah baik. Nilai latent variable dalam penelitian ini juga rendah yaitu sebesar 4 , semua nilai itu dapat dilihat pada Gambar 3.

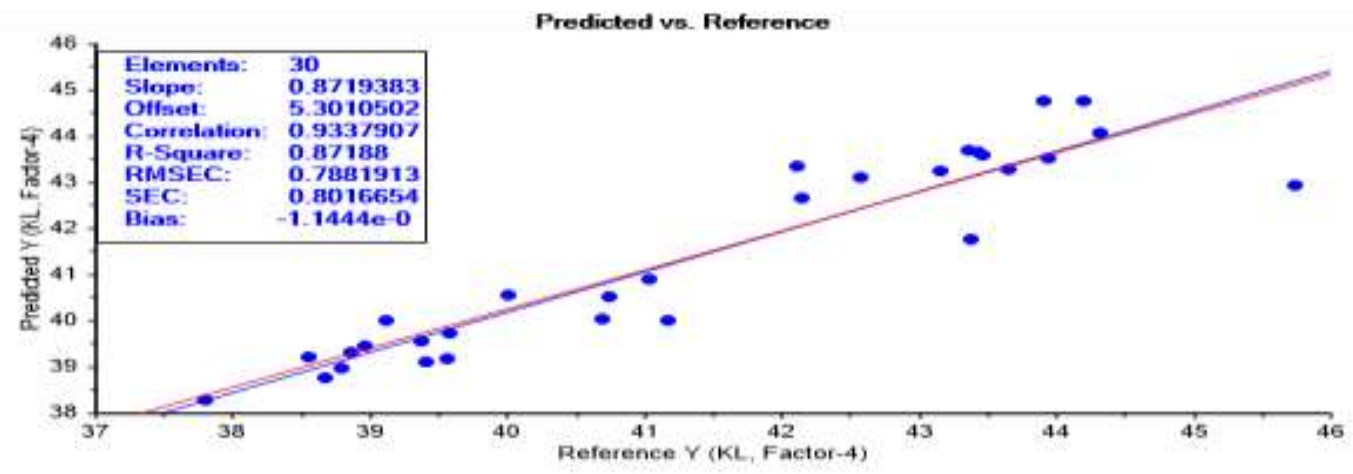

Gambar 3. Plot Data Kalibrasi Non Pretreatment

Pemakaian pretreatment mean normalization telah meningkatkan kinerja PLS hasil pendugaan seperti yang terlihat pada Gambar 4. Hal ini bisa dilihat dari nilai koefisien korelasi (r) yang meningkat menjadi 0,95. Menurut William dan Norris (1990) nilai $r$ di atas 0,90 sudah baik. Nilai koefisien determinasi $\left(\mathrm{R}^{2}\right)$ yang meningkat menjadi 0,90. Menurut Karoui et al. (2005) nilai $\mathrm{R}^{2}$ antara 0,82-0,90 menyatakan dugaan baik, kemudian nilai error (RMSEC) yang semakin kecil yaitu 0,70. Menurut William dan Norris (1990) nilai error lebih kecil dari standar deviasi data aktual sudah baik. Nilai latent variable sebesar 5. 


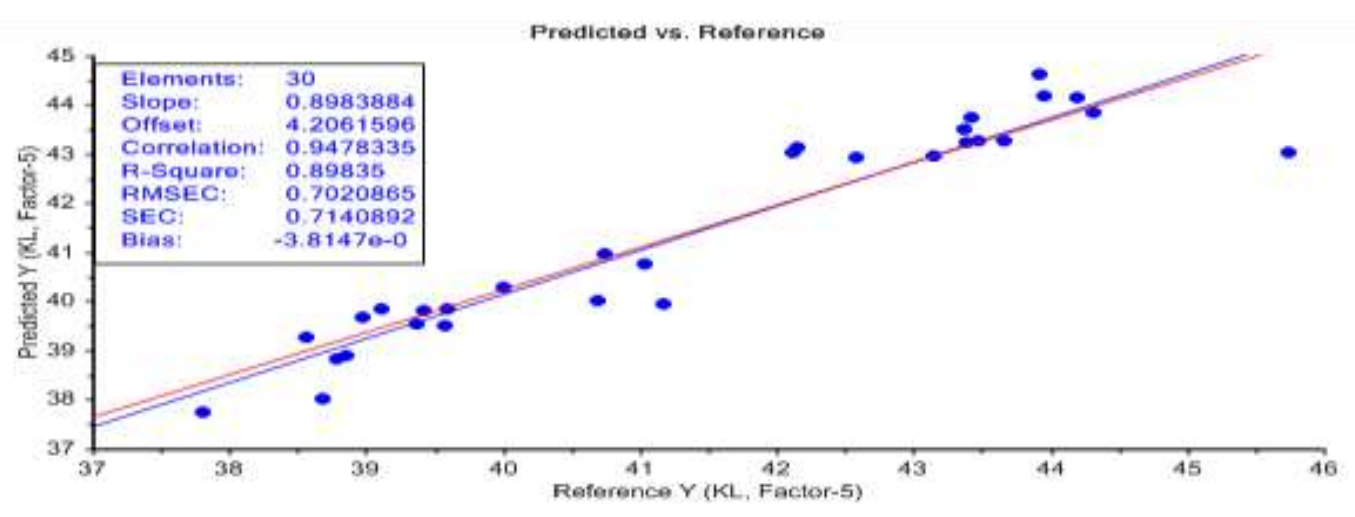

Gambar 4. Plot Data Kalibrasi MN + PLS

Pemakaian pretreatment de-trending juga dapat meningkatkan kinerja PLS hasil pendugaan seperti yang terlihat pada Gambar 5. Hal ini bisa dilihat dari nilai koefisien korelasi (r) yang meningkat menjadi 0,96. Menurut William dan Norris (1990) nilai $\mathrm{r}$ di atas 0,90 sudah baik. Nilai koefisien determinasi $\left(\mathrm{R}^{2}\right)$ yang meningkat menjadi 0,92. Menurut Karoui et al. (2005) nilai $\mathrm{R}^{2}$ diatas 0,91 menyatakan dugaan sangat baik, sementara nilai error (RMSEC) yang semakin kecil yaitu 0,60. Menurut William dan Norris (1990) nilai error lebih kecil dari standar deviasi data aktual sudah baik. Nilai latent variable sebesar 6. Hasil kalibrasi untuk non pretreatment, mean normalization, dan de-trending dapat dilihat pada Tabel 1.

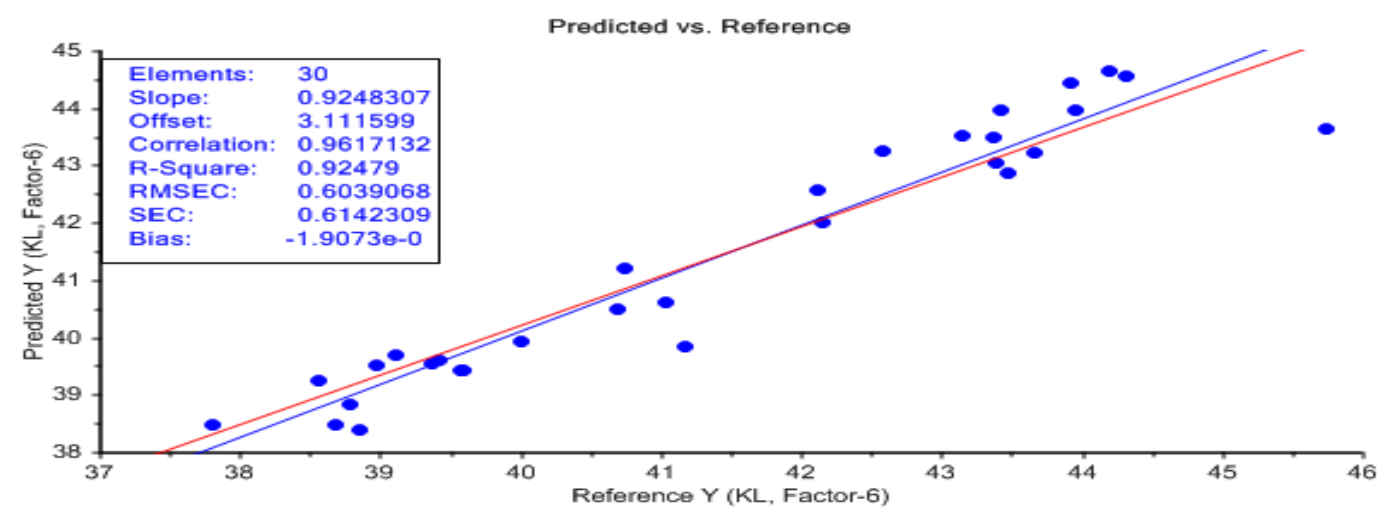

Gambar 5. Plot Data Kalibrasi DT + PLS

Tabel 1. Hasil Kalibrasi kadar Lemak Bubuk Biji kakao

\begin{tabular}{lcccc}
\hline Perlakuan & Latent variable & $\mathrm{r}$ & $\mathrm{R}^{2}$ & $\begin{array}{c}\text { RMSEC } \\
(\%)\end{array}$ \\
\hline Non pretreatment & 4 & 0,93 & 0,87 & 0,79 \\
Mean Normalization & 5 & 0,95 & 0,90 & 0,70 \\
De - Trending & 6 & 0,96 & 0,92 & 0,60 \\
\hline
\end{tabular}

\section{Validasi Silang (Cross Validation)}

Selanjutnya dilakukan cross validation untuk menilai/memvalidasi keakuratan model kalibrasi yang telah dibangun berdasarkan dataset penelitian. Pada penelitian ini dipakai $k$-fold cross validation untuk membagi dataset menjadi sejumlah segment. Sampel yang digunakan adalah 30 sampel yang dibagi menjadi 10 segment dan sampel per segment adalah 3.

Hasil pendugaan cross validation non pretreatment menghasilkan nilai koefisien korelasi (r) yang cukup tinggi yaitu 0,90. Menurut William dan Norris (1990) nilai r di atas 
0,90 sudah baik. Nilai koefisien determinasi $\left(\mathrm{R}^{2}\right)$ yang cukup bagus yaitu 0,82 . Menurut Karoui et al. (2005) nilai $\mathrm{R}^{2}$ antara 0,82-0,90 menyatakan dugaan baik, nilai error (RMSECV) yaitu 0.96. Menurut William dan Norris (1990) nilai error lebih kecil dari standar deviasi data aktual sudah baik. Nilai dRMSE yaitu 0,18. Selanjutnya jika dilihat dari nilai RPD, ternyata masih diatas dua yaitu 2,33. Menurut Nicolai et al. (2007) nilai RPD yang berada dalam selang $2-$ 2,5 menandakan bahwa model itu termasuk good model performance, semua nilai itu dapat dilihat pada Gambar 6.

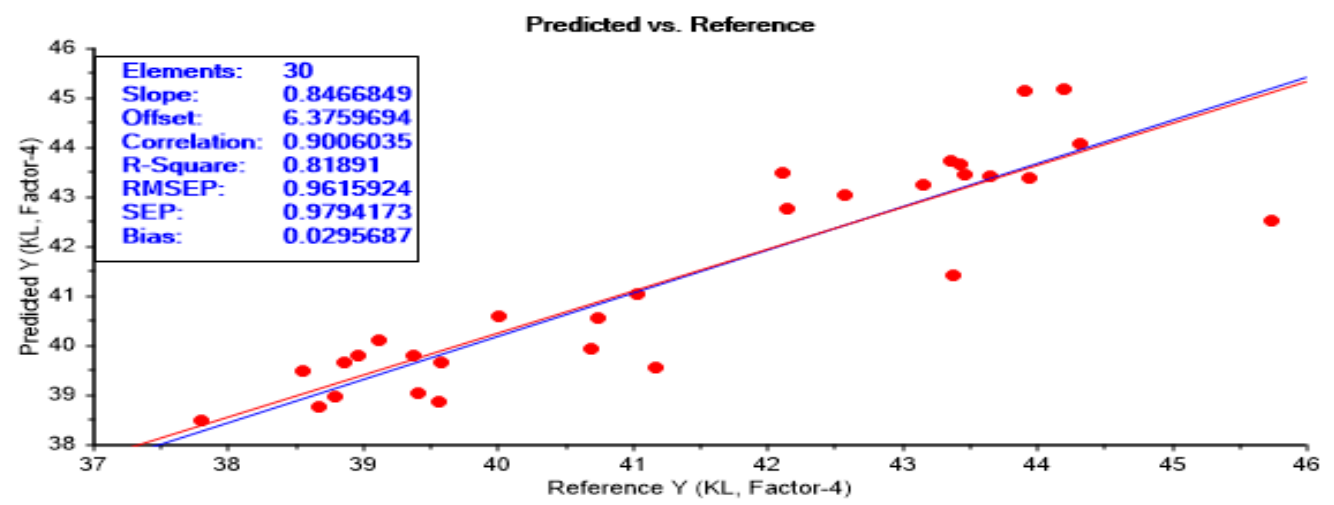

Gambar 6. Plot Data Cross Validation Non Pretreatment

Pemakaian pretreatment mean normalization dapat meningkatkan kinerja PLS hasil pendugaan seperti yang terlihat pada Gambar 7. Hal ini bisa dilihat dari nilai koefisien korelasi (r) yang meningkat menjadi 0,91. Menurut William dan Norris (1990) nilai $r$ di atas 0,90 sudah baik. Nilai $\mathrm{R}^{2}$ yang meningkat menjadi 0,84. Menurut Karoui et al. (2005) nilai $\mathrm{R}^{2}$ antara 0,820,90 menyatakan dugaan baik, kemudian nilai error (RMSECV) yang semakin kecil menjadi 0,92. Menurut William dan Norris (1990) nilai error lebih kecil dari standar deviasi data aktual sudah baik. Nilai dRMSE 0.20. Selanjutnya jika dilihat dari nilai RPD cenderung meningkat menjadi 2,43, nilai RPD yang berada dalam selang 2 - 2,5 menandakan bahwa model itu termasuk good model performance.

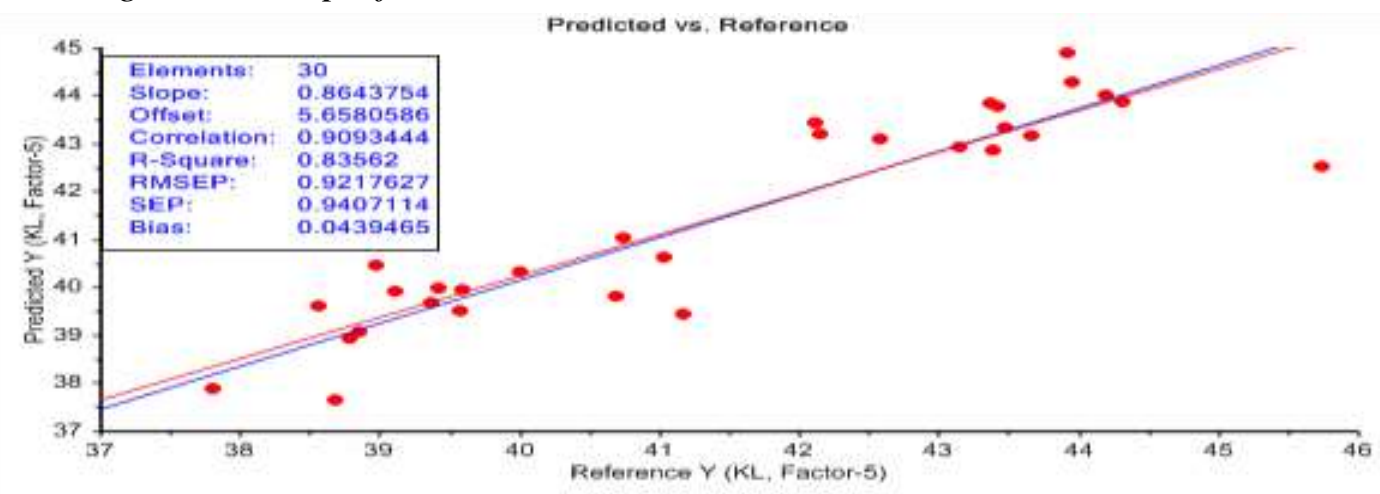

Gambar 7. Plot Data Cross Validataion MN+ PLS

Pemakaian pretreatment de-trending dapat meningkatkan kinerja PLS hasil pendugaan seperti yang terlihat pada Gambar 8. Hal ini bisa dilihat dari nilai koefisien korelasi (r) yang meningkat menjadi 0,91. Menurut William dan Norris (1990) nilai $\mathrm{r}$ di atas 0,90 sudah baik. Nilai koefisien determinasi $\left(\mathrm{R}^{2}\right)$ yang meningkat menjadi 0,84. Menurut Karoui et al. (2005) nilai $\mathrm{R}^{2}$ antara 0,82-0,90 menyatakan dugaan baik, kemudian nilai error (RMSECV) yang semakin kecil menjadi 0,92. Menurut William dan Norris (1990) nilai error lebih kecil dari standar deviasi data aktual sudah baik. Nilai dRMSE 0,31. Selanjutnya jika dilihat dari nilai 
RPD pretreatment ini menghasilkan nilai yang paling besar yaitu 2,46, nilai RPD yang berada dalam selang 2 - 2,5 menandakan bahwa model itu termasuk good model performance.

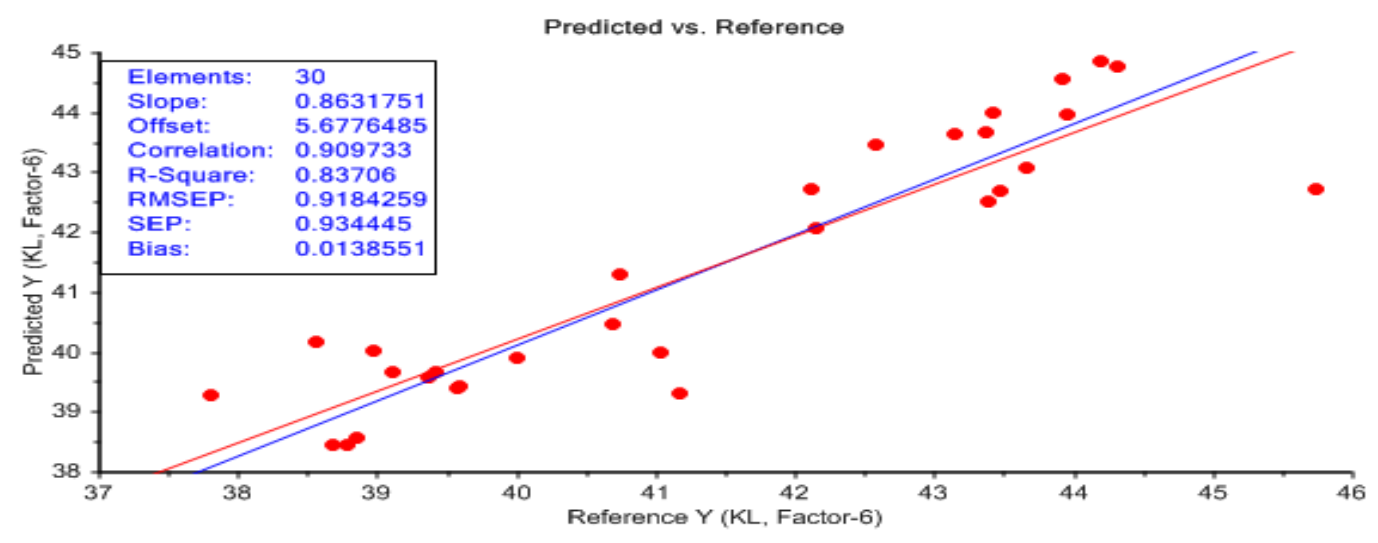

Gambar 8. Plot Data Cross Validation DT+ PLS

Tabel 2. Hasil Validasi Silang (Cross Validation) kadar Lemak Bubuk Biji Kakao

\begin{tabular}{lccccc}
\hline Perlakuan & $\mathrm{r}$ & $\mathrm{R}^{2}$ & $\begin{array}{c}\text { RMSECV } \\
(\%)\end{array}$ & dRMSE & $\mathrm{RPD}$ \\
\hline Non pretreatment & 0,90 & 0,82 & 0,96 & 0,18 & 2,33 \\
Mean Normalization & 0,91 & 0,84 & 0,92 & 0,20 & 2,43 \\
De - Trending & 0,91 & 0,84 & 0,92 & 0,31 & 2,46 \\
\hline
\end{tabular}

Tabel 2. menunjukkan kemampuan PLS menduga kadar lemak pada bubuk biji kakao dapat dikatakan bagus dilihat dari hasil cross validation. PLS tanpa pretreatment masih menghasilkan model yang tergolong kedalam good model performance walaupun nilai $\mathrm{r}$ cross validation berkurang 3,22\% dari $\mathrm{r}$ kalibrasi, nilai dRMSE sebesar 0,18, dan nilai RPD 2,33. Selanjutnya pemberian PLS dengan penambahan pretreatment mean normalization juga menghasilkan model yang tergolong kedalam good model performance walaupun nilai $\mathrm{r}$ cross validasi berkurang 3,19\% dari r kalibrasi, nilai dRMSE sebesar 0,20, dan nilai RPD yang meningkat menjadi 2,43. Kemudian pemberian PLS dengan penambahan pretreatment detrending juga menghasilkan model yang tergolong kedalam good model performance walaupun nilai $\mathrm{r}$ cross validasi berkurang 5,20\% dari r kalibrasi, nilai dRMSE sebesar 0,31 , dan nilai RPD yang meningkat menjadi 2.46. Dapat disimpulkan bahwa yang paling baik dalam meningkatkan performa kinerja PLS adalah de-trending dilihat dari nilai RPD yang paling besar yaitu 2,46 yang tergolong kedalam good model performance, nilai koefisien korelasi ( $\mathrm{r}$ ) yang tinggi 0,91 , nilai koefisien determinasi $\left(\mathrm{R}^{2}\right)$ yang bagus 0,84 , dan nilai error (RMSECV) yang paling kecil yaitu 0,92 .

\section{KESIMPULAN DAN SARAN}

Panjang gelombang 2300-2400 nm merupakan panjang gelombang yang relevan untuk menduga kadar lemak pada bubuk biji kakao. Penambahan pretreatment (mean normalization dan de-trending) mampu meningkatkan kinerja model yang tergolong good model performance. Pretreatment terbaik yang dapat meningkatkan performa PLS hasil pendugaan adalah de-trending dilihat dari nilai RPD yang paling besar 2,46 yang tergolong good model performance, nilai $\mathrm{r}$ yang tinggi $0,91, \mathrm{R}^{2}$ yang bagus 0,84 , dan nilai error (RMECV) yang paling kecil 0,92. 


\section{DAFTAR PUSTAKA}

[BPS] Badan Pusat Statistik. 2013. Aceh dalam Angka.

[BSN] Badan Standarisasi Nasional. 2008. Parameter Mutu dan Pengukuran Standarisasi Kakao dan Kopi.

Cen, H dan Y.He. 2007. Theory and Application of Near Inrfrared Reflectance Spectroscopy in Determination of Food Quality. J. Trends in Food Sci \&Technol 18: 72-83.

Florez, K.,M. T.Sanchez, D.Perez-Marin, J. E.Guerrero, A.G. Varo. 2009. Feasibility in NIRS Instrument for Predicting Internal Quality in Intact Tomato. J. Food Engineering. 91: 311-318

International Cocoa Organization. 2015. ICCO Quarterly of Cocoa Statistic.

Jha, S. N., A.R.P. Kingsly, S.Chopra. 2006. Non-Destruktif Determination of Firmness and Yellowness of Mango During Growth and Storage Using Visual Spectroscopy. J. Biosystem Engineering. 94: 397-402.

Mulato, S., S.Widyotomo, Miswani, E.Suharyanto. 2009. Pengolahan Produk Primer dan Sekunder Kakao. Pusat Penelitian Kopi dan Kakao Indonesia. Jember.

Nicolai, B. M., K.Beullens, E.Bobelyn, A.Peirs, W.Saeys, K. I.Theron, J.Lamertyn. 2007. Nondestructive Measurement of Fruit and Vegetable Quality by Means of NIRSpectroscopy : A Review. Postharvest Biology and Technology. 46: 99-118.

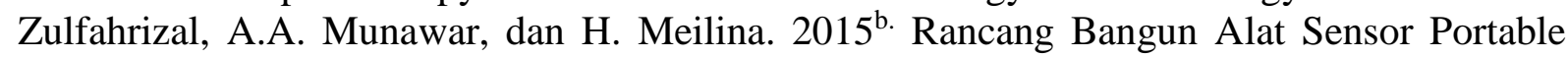
Berbasis Pengembangan Aplikasi Teknologi Near Infrared sebagai Metode Baru yang Rapid dan Non-Destruktif untuk Prediksi Kualitas Kakao. Laporan Penelitian Pengembangan Ilmu Pengetahuan dan Teknologi. Universitas Syiah Kuala. 